\title{
KERANGKA KERJA TATA KELOLA TEKNOLOGI INFORMASI UNTUK LAYANAN TI MENGGUNAKAN COBIT 5 DAN ITIL V.3 (Studi Kasus : Sekolah Tinggi Teknologi Indonesia Tanjungpinang)
}

\author{
Liza Safitri* ${ }^{1}$, Dana Indra Sensuse $*^{2}$ \\ Magister Teknik Informatika Universitas AMIKOM Yogyakarta

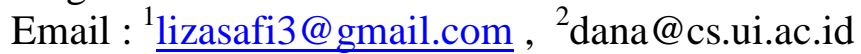

\begin{abstract}
Abstrak
Pemanfaatan teknologi dalam sektor pelayanan pendidikan dilakukan untuk memberikan kemudahan pada proses administrasi bagi perguruan tinggi yang menerapkannya. Namun dalam kenyataannya penggunaan sistem informasi dalam memberikan layanan terhadap kebutuhan TI masih memiliki banyak risiko seperti ketersediaan data, kehilangan data, pemrosesan data yang salah sehingga layanan akademik tidak berjalan dengan efisien. Risiko-risiko tersebut dapat mempengaruhi tingkat efektifitas dan efisiensi dalam pencapaian tujuan dan strategi Sekolah Tinggi Teknologi Indonesia Tanjungpinang.

Dalam melakukan pemenuhan kebutuhan teknologi informasi diperlukan adanya sebuah mekanisme evaluasi dan kontrol terhadap pengelolaan teknologi informasi. Mekanisme kontrol serta audit Sistem Informasi dan audit Teknologi Informasi yang digunakan adalah audit kerangka kerja COBIT 5 dan ITIL V.3, dimana IT assurance ini bukan hanya dapat memberikan evaluasi terhadap tata kelola Teknologi Informasi pada Sekolah Tinggi Teknologi Indonesia Tanjungpinang, tetapi dapat juga memberikan panduan yang dapat dipergunakan untuk melakukan perbaikan pengelolaan teknologi informasi pada Sekolah Tinggi Teknologi Indonesia Tanjungpinang dimasa yang akan datang. Metodologi yang digunakan dalam penelitian ini dimulai dari melakukan pemetaan COBIT 5 dan ITIL V.3 kemudian dilakukan pemilihan proses-proses yang relevansi terhadap masalah yang dihadapi organisasi. Framework baru tersebut dilakukan penilaian untuk mendapatkan nilai dan dilakukan Gap analysis untuk mendapatkan rekomendasi aktifitas proses IT.

Berdasarkan hasil pengukuran tingkat evaluasi framework tata kelola teknologi informasi untuk layanan TI pada Sekolah Tinggi Teknologi Indonesia Tanjungpinang menggunakan COBIT 5 dan ITIL V.3 diketahui bahwa Sekolah Tinggi Teknologi Indonesia Tanjungpinang berada pada level L (Largely achieved) dimana L sebagian besar dicapai (> prestasi 50\% untuk $85 \%)$.
\end{abstract}

Kata kunci: COBIT 5, ITIL V3, Kerangka Kerja, STT Indonesia Tanjungpinang

\section{PENDAHULUAN}

Teknologi informasi memberikan banyak kemudahan bagi semua aspek kegiatan bisnis. Penggunaan teknologi informasi melingkupi sistem yang pengumpulan, penyimpanan, pemprosesan, memproduksi dan mengirimkan informasi dari dan ke seluruh aspek bisnis ataupun masyarakat secara efektif dan cepat. Berbagai macam cara dan upaya dilakukan untuk memanfaatkan teknologi informasi untuk melakukan sebuah perubahan. Pada kondisi tersebut, dipicu adanya upaya untuk melepaskan dunia pendidikan dari lingkup model pembelajaran dan pendidikan yang dahulunya konvensional dan manual, yang semakin hari semakin membosankan dan tidak menarik. Menurut Nanang (2014) dunia pendidikan merupakan sebuah ruang bagi pengalaman manusia yang tidak steril dari berbagai macam kepentingan. Oleh karena itu, dunia pendidikan dituntut untuk dapat secara terus-menerus mengikuti alur perkembangan teknologi 
serta ilmu pengetahuan yang semakin berkembang pesat, karena jika pendidikan masih tetap berkutat pada instruksional kurikulum yang kaku hanya akan menjadikan peserta didik juga kaku terhadap realita kemajuan teknologi yang semakin tak terbendung.

Penerapan teknologi pada dunia pendidikan, diharapkan akan mampu menggeser sifat pendidikan yang cenderung tertutup (introvet) menjadi terbuka (ekstrovet) dan lebih proaktif, sehingga akan semakin menjadikan proses belajar mengajar menjadi lebih kreatif, kompetitif, dan berkompeten. Teknologi informasi pada dunia pendidikan sudah banyak diterapkan, dan salah satunya pada Sekolah Tinggi Teknologi Indonesia Tanjungpinang. Adapun pemanfaatan teknologi pada Sekolah Tinggi Teknologi Indonesia Tanjungpinang dilakukan untuk pemenuhan kebutuhan akan sistem informasi dalam sektor pelayanan pendidikan. Salah satunya dengan tersedianya Sistem Informasi Akademik dan Keuangan yang merupakan pemenuhan kebutuhan yang mutlak dalam memberikan pelayanan pendidikan pada perguruan tinggi, yang dapat memberikan kemudahan pada proses administrasi bagi perguruan tinggi yang menerapkannya. Namun dalam kenyataannya penggunaan sistem informasi dalam memberikan layanan terhadap kebutuhan TI masih memiliki banyak risiko. Risiko yang sering terjadi pada sistem yang terdapat pada Sekolah Tinggi Teknologi Indonesia Tanjungpinang adalah ketersediaan data pada saat mahasiswa sedang melaksanakan ujian akhir semester akibat dari penggunaan internet yang overload, sehingga menyebabkan layanan ujian akhir semester menjadi tertunda, selain itu juga sering terjadi kehilangan data sehingga layanan akademik tidak berjalan dengan efisien. Risiko lain yang sering dihadapi diakibatkan oleh pemrosesan data yang salah sehingga pada saat pengambilan keputusan juga dapat berpengaruh.

Oleh karena alasan tersebut maka diperlukan adanya sebuah mekanisme evaluasi dan kontrol terhadap pengelolaan teknologi informasi, sehingga diperlukan sebuah mekanisme kontrol serta audit Sistem Informasi dan audit Teknologi Informasi. Audit kerangka kerja COBIT 5 dan ITIL V.3 lebih sering disebut dengan istilah IT Assurance yang bukan hanya dapat memberikan evaluasi terhadap tata kelola Teknologi Informasi pada Sekolah Tinggi Teknologi Indonesia Tanjungpinang, tetapi dapat juga memberikan panduan yang dapat dipergunakan untuk melakukan perbaikan pengelolaannya dimasa yang akan datang.

Penggunaan framework COBIT 5 dapat membantu sebuah perusahaan dalam menciptakan nilai optimal dari IT dengan menjaga keseimbangan antara manfaat dan mengoptimalkan tingkat risiko dan penggunaan sumber daya, sehingga sebuah perusahaan dapat memberikan nilai terhadap tata kelola TI yang mereka gunakan. ITIL menyediakan sebuah kerangka kerja yang konsisten dan koheren untuk praktik terbaik ITSM dan proses yang terkait, yang mempromosikan pendekatan kualitas untuk mencapai bisnis efektivitas dan efisiensi dalam penggunaan sistem informasi (Samiotakis, 2013). Hal tersebut dapat dibuktikan dengan penelitian yang telah dilakukan oleh (Zeinolabedin, et al, 2014) yang mengungkapkan bahwa COBIT dapat melengkapi ITIL untuk mencapai Alignment bisnis IT. (Almaeda, et al, 2016 ) juga menganalisis dampak dari proses manajemen insiden dan meminta pemenuhan dengan mengunakan ITIL dan COBIT 5. Dengan adanya permasalahan tersebut maka penulis melakukan penelitian tentang tata kelola TI dengan mengunakan ITIL V.3 dan COBIT 5 sehingga penelitian ini dapat menghasilkan sebuah kerangka kerja layanan TI yang tepat untuk Sekolah Tinggi Tekonologi Indonesia Tanjungpinang.

\section{LANDASAN TEORI}

\subsection{Tata Kelola Teknologi Informasi}


Definisi teknologi informasi menurut (Nuryanto, 2012) adalah suatu teknologi yang digunakan untuk mengolah data, meliputi; memproses, menyimpan, mendapatkan, menyusun, memanipulasi data dengan berbagai cara untuk menghasilkan informasi yang berkualitas. Teknologi informasi merupakan sebuah payung besar dalm terminologi yang mencangkup seluruh kegiatan pada teknis untuk memproses dan menyampaikan sebuah informasi, sehingga dibutuhkan sebuah tata kelola teknologi informasi didalamnya untuk melakukan segala proses pengontrolan yang terdapat didalam teknologi.

\subsection{COBIT 5}

Pengertian COBIT 5 (ISACA, 2013) adalah sebuah kerangka yang komprehensif untuk membantu perusahaan dalam mencapai tujuan mereka dalam dunia pemerintahan dan pengelolaan perusahaan teknologi informasi (TI). COBIT 5 digunakan untuk membantu perusahaan dalam menciptakan nilai TI yang optimal dengan cara menjaga keseimbangan antara mewujudkan manfaat dan pengoptimalan tingkat risiko dan resource (sumber daya) yang digunakan. Perkembangan COBIT 5 sebagai enabling proses terhadap pengontrolan teknologi informasi dapat dilihat pada gambar dibawah ini :

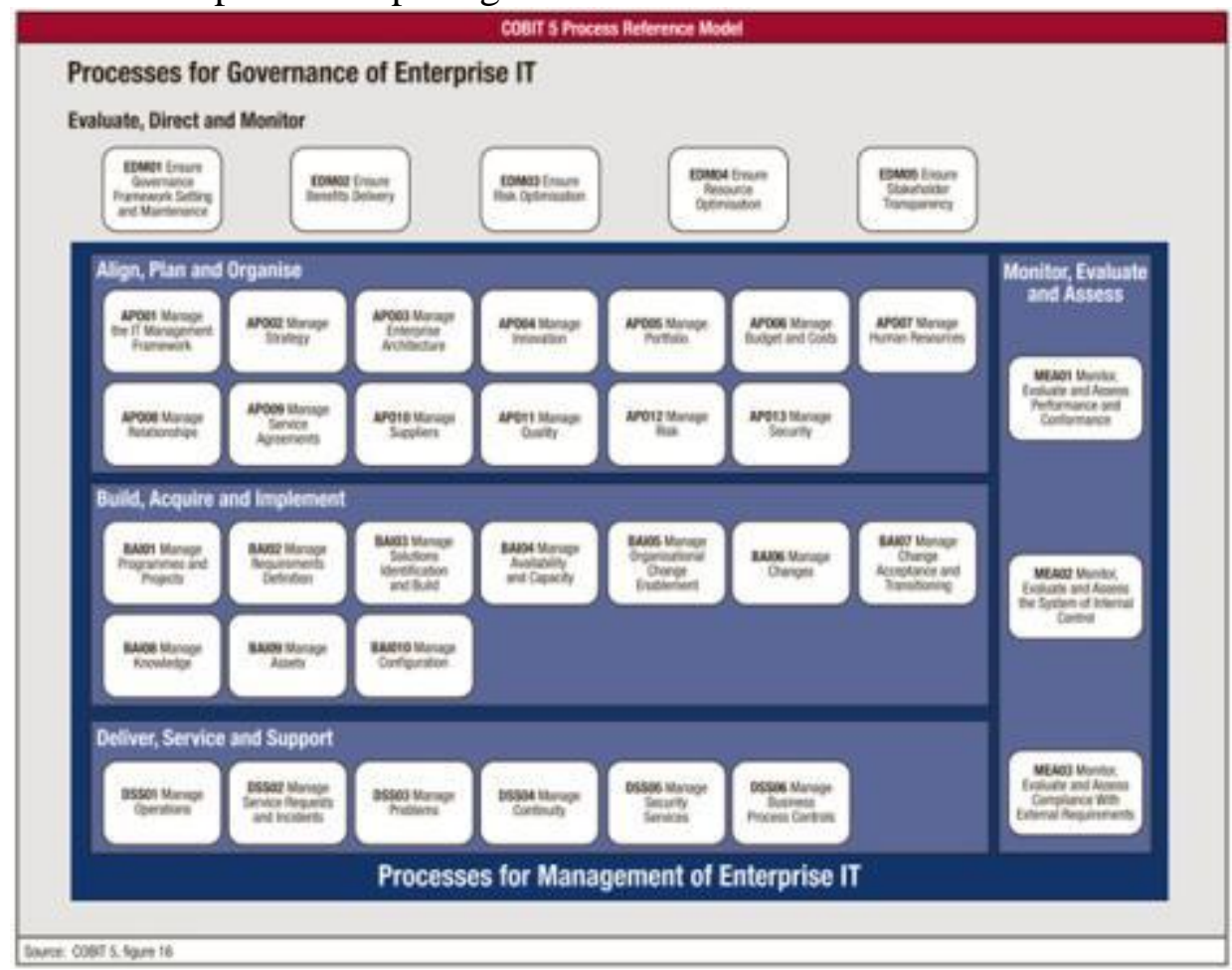

Gambar 2.1 COBIT 5 Illustrative Governance dan manajemen proses (sumber : isaca.org)

Didalam COBIT 5 terdapat 5 Prinsip COBIT 5 yang digunakan untuk memandu melalui fase-fasenya yang dibagi ke dalam implementasi program ke dalam fase berikut: pelatihan dan kesadaran, gap penilaian, pelaksanaan desain dan pengelolaan program. Lima (5) prinsip dalam COBIT 5:

1. Prinsip 1: Pemenuhan Kebutuhan Stakeholder : Melakukan penciptaan nilai bagi para stakeholder dengan menyeimbangkan antara realisasi keuntungan dengan optimasi risiko dan penggunaan sumber daya. 
2. Prinsip 2 : Lingkup Seluruh Perusahaan : pengelolaan informasi dan teknologi yang terkait dari enterprisewide, perspektif end-to-end.

3. Prinsip 3 : Penerapan Kerangka Tunggal yang Terintegrasi : memberikan dasar untuk mengintegrasikan secara efektif lain kerangka, standar dan praktek-praktek yang digunakan. Satu kerangka menyeluruh berfungsi sebagai sumber yang konsisten dan bimbingan terpadu dalam bahasa yang umum non-teknis, teknologi-agnostik.

4. Prinsip 4 : Penggunaan pendekatan yang menyeluruh : melakukan pendekatan terhadap prinsip, keamanan dan framework, terhadap proses struktur organisasi, kultur dan etnik serta pendekatan terhadap resource.

5. Prinsip 5 : Pemisahan Tata kelola Dari Manajemen : melakukan pengelolaan domain, monitoring kegiatan-kegiatan, mengecek sejauh arah yang telah ditetapkan untuk manajemen sebenarnya.

\subsection{ITIL}

The IT Infrastructure Library (ITIL) merupakan suatu framework pengelolaan layanan TI (IT Service). Menurut (Tarigan, 2010) The IT Infrastructure Library (ITIL) adalah suatu rangkaian konsep dan teknik pengelolaan infrastruktur, pengembangan, serta operasi TI. Standar ITIL berfokus kepada pelayanan customer, dan sama sekali tidak menyertakan proses penyelarasan strategi perusahaan terhadap strategi TI yang dikembangkan.

Standar ITIL berfokus pada pelayanan customer, dan ITIL sama sekali tidak menyertakan proses penyelarasan strategi perusahaan terhadap strategi TI yang sedang dikembangkan.

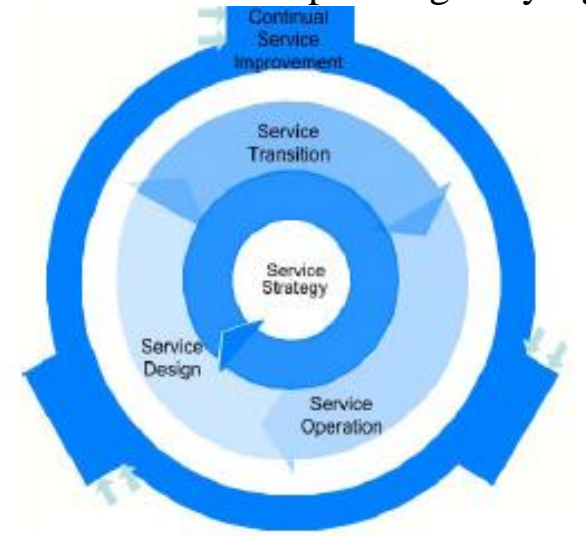

Gambar 2.2 ITIL® Service Lifecycle Model (The Art of Service, 2009)

Lima bidang utama proses yang digambarkan dalam model diatas adalah

1. Service Strategy : pada fase ini terdiri dari design, pengembangan dan implementasi manajemen layanan sebagai sumber daya strategis.

2. Service Design : pada fase ini terdiri tahapan pengembangan layanan TI yang sesuai, termasuk arsitektur, proses, kebijakan dan dokumen, tujuan desain adalah untuk memenuhi kebutuhan saat ini dan kebutuhan bisnis masa depan.

3. Service Transition : tahap mengembangkan dan meningkatkan kemampuan untuk transisi layanan baru dan dimodifikasi untuk produksi.

4. Service Operation : fase ini untuk mencapai efektivitas dan efisiensi dalam menyediakan dan mendukung layanan dan untuk memastikan nilai kepada nasabah dan layanan penyedia.

5. Continual Service Improvement : fase menciptakan dan mempertahankan nilai untuk pelanggan oleh perbaikan Desain, dan layanan pengenalan dan pengoperasian. 


\section{METODOLOGI PENELITIAN}

Berikut merupakan tahapan metodologi penilitian yang digunakan:

a. Penentuan ruang lingkup penelitian : pada tahapan ini akan dilakukan penentuan tempat penelitian yaitu di Sekolah Tinggi Teknologi Indonesia Tanjungpinang yang beralamatkan di Jl. Brigjen Katamso No. $92 \mathrm{Km} \mathrm{2,5}$ Tanjungpinang, sedangkan untuk penetapan metode yang digunakan untuk melakukan penelitian ini adalah COBIT 5 dan ITIL V.3.

b. Pengumpulan data : pada tahap ini akan dilakukan pengumpulan data berupa penyebaran kuisioner kepada para Staf dan Karyawan Sekolah Tinggi Teknologi Indonesia Tanjungpinang, dan melakukan wawancara kepada pihak sumber informasi yaitu Puskom (Pusat Komunikasi) dan Puslahta (Pusat Pengolahan Data). Selain itu juga akan dilakukan observasi, dengan melakukan penelitian atau pengamatan langsung kelapangan, yaitu ke Sistem Informasi Manajemen Akademik dan Keuangan (SIMAK) dan Sistem Informasi Ujian Akhir Semester (SIUAS).

c. Penilaian layanan TI : pada fase ini dilakukan penilaian efektifitas dan efisiensi terhadap layanan TI yang terdapat pada Sekolah Tinggi Teknologi Indonesia Tanjungpinang.

d. Perancangan framework : setelah dilakukan penilaian terhadap layanan TI pada Sekolah Tinggi Teknologi Indonesia Tanjungpinang, akan dirancang sebuah panduan (framework) dengan menggunakan ITIL V.3 dan COBIT 5.

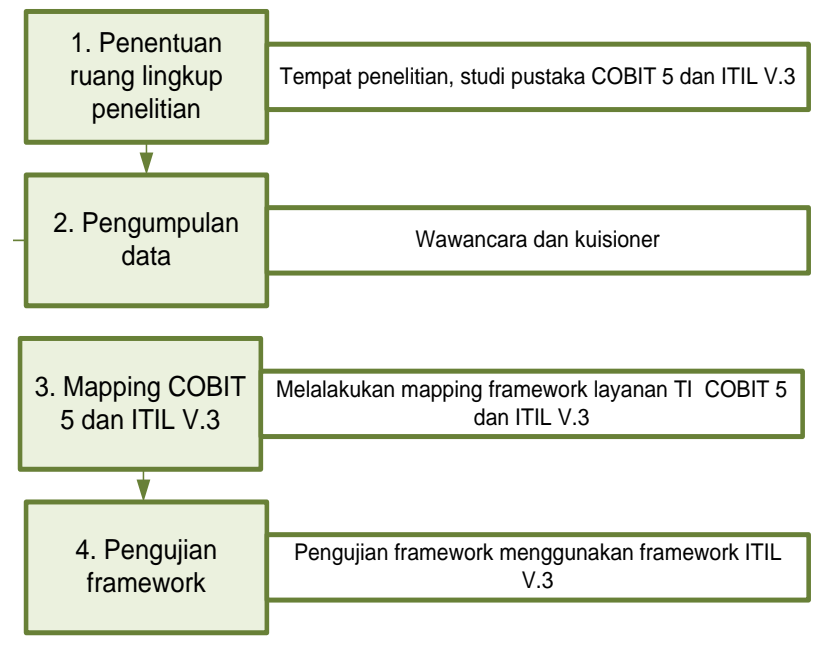

Gambar 3.1 Tahapan Penelitian

\section{ANALISIS DAN PEMBAHASAN}

\subsection{Mapping COBIT 5 dan ITIL V.3}

Mapping COBIT 5 dan ITIL V. 3 dilakukan untuk mendapatkan komponen-komponen Framework dan dilakukan analisis terhadap komponen-komponen tersebut untuk mendapatkan komponen yang sesuai.

Tabel 4.1 Pemetaan ITIL V3 dan COBIT 5

\begin{tabular}{l|l|l} 
No & COBIT 5 & ITIL V3
\end{tabular}




\begin{tabular}{|c|c|c|}
\hline 1 & EDM02 Ensure benefits delivery & Service portfolio management \\
\hline 2 & EDM04 Ensure resource optimisation & Demand management \\
\hline 3 & EDM05 Ensure stakeholder transparency & Business relationship management \\
\hline 4 & $\begin{array}{l}\text { APO01 Manage the IT management } \\
\text { framework }\end{array}$ & The Seven-Step Improvement \\
\hline 5 & APO02 Manage strategy & Strategy management for IT services \\
\hline \multirow{2}{*}{6} & \multirow{2}{*}{ APO05 Manage portfolio } & Service portfolio management \\
\hline & & Service catalogue management \\
\hline 7 & APO06 Manage budget and costs & Financial management for IT services \\
\hline 8 & APO07 Manage human resources & Capacity management \\
\hline 9 & APO08 Manage relationships & Demand management \\
\hline \multirow{6}{*}{10} & \multirow{6}{*}{ APO09 Manage service agreements } & Business relationship management \\
\hline & & Service portfolio management \\
\hline & & Demand management \\
\hline & & Service catalogue management \\
\hline & & Service level management \\
\hline & & Service reporting \\
\hline 11 & APO10 Manage suppliers & Supplier management \\
\hline 12 & APO11 Manage quality & The Seven-Step Improvement \\
\hline 13 & APO12 Manage risk & Information security management \\
\hline 14 & APO13 Manage security & Information security management \\
\hline 15 & BAI01 Manage programmes and projects & Design coordination \\
\hline 16 & BAI02 Manage requirements definition & Service level management \\
\hline \multirow{2}{*}{17} & \multirow{2}{*}{ BAI04 Manage availability and capacity } & Availability management \\
\hline & & Capacity management \\
\hline 18 & BAI06 Manage changes & Change management \\
\hline \multirow{5}{*}{19} & \multirow{5}{*}{$\begin{array}{l}\text { BAI07 Manage change acceptance and } \\
\text { transitioning }\end{array}$} & Design coordination \\
\hline & & Transition planning and support \\
\hline & & Release and deployment management \\
\hline & & Service validation and testing \\
\hline & & Change evaluation \\
\hline 20 & BAI08 Manage knowledge & Knowledge management \\
\hline 21 & BAI09 Manage assets & $\begin{array}{l}\begin{array}{l}\text { Service asset and configuration } \\
\text { management }\end{array} \\
\end{array}$ \\
\hline 22 & BAI10 Manage configuration & $\begin{array}{l}\text { Service asset and configuration } \\
\text { management }\end{array}$ \\
\hline \multirow{2}{*}{23} & \multirow{2}{*}{ DSS01 Manage operations } & Event management \\
\hline & & IT operations management \\
\hline \multirow{2}{*}{24} & \multirow{2}{*}{$\begin{array}{l}\text { DSS02 Manage service requests and } \\
\text { incidents }\end{array}$} & Incident management \\
\hline & & Request fulfilment \\
\hline
\end{tabular}




\begin{tabular}{|l|l|l|}
25 & DSS03 Manage problems & Problem management \\
\hline 26 & DSS04 Manage continuity & $\begin{array}{l}\text { IT service continuity management } \\
\text { ITSCM) }\end{array}$ \\
\hline 28 & DSS05 Manage security services & Information security management \\
\hline 29 & $\begin{array}{l}\text { DES06 Manage business process controls } \\
\text { performance and conformance }\end{array}$ & Access management \\
\hline 30 & $\begin{array}{l}\text { MEA02 Monitor, evaluate and assess the } \\
\text { system of internal control }\end{array}$ & Service measurement \\
\cline { 2 - 3 } 31 & $\begin{array}{l}\text { MEA03 Monitor, evaluate and assess } \\
\text { compliance with external requirements }\end{array}$ & The Seven-Step Improvement \\
\hline
\end{tabular}

Dari tabel hasil pemetaan diatas, pemilihan proses-proses dilakukan untuk menentukan kebutuhan proses yang dibutuhkan sesuai dengan permasalahan yang ada di Sekolah Tinggi Teknologi Indonesia Tanjungpinang. Sesuai dengan ruang lingkup yang ada pada penelitian ini bahwa fokus penelitian hanya pada 3 (tiga) proses service lifecycle yaitu Service Design, Service Transition serta Service Operation, Oleh karena itu dari ketiga puluh satu proses COBIT 5 yang telah dipetakan, akan dilakukan pemetaan kembali untuk menyesuaikan dengan terhadap domain service lifecycle Service Design, Service Transition serta Service Operation. Dari Hasil pemetaan tersebut didapatkan hasil 20 proses COBIT 5 dengan 3 (tiga) domain yaitu domain Align, Plan and Organise (APO), domain Build, Acquire and Implement (BAI) dan Deliver, serta domain Service and Support (DSS).

\subsection{Pemilihan Proses-proses Baru}

Berdasarkan hasil pemetaan dari framework COBIT 5 dan ITIL V3 didapatkan hasil berupa 20 proses COBIT 5 yang kemudian akan dilakukan pemilihan lebih lanjut untuk mendapatkan proses-proses baru yang relevan dengan permasalahan yang dihadapi oleh Sekolah Tinggi Teknologi Indonesia Tanjungpinang.

Tabel 4.2 Pemetaan COBIT 5 dengan permasalahan

\begin{tabular}{|r|l|c|l|}
\hline No & \multicolumn{1}{|c|}{ COBIT 5 } & Masalah & \multicolumn{2}{|c|}{ Keterangan } \\
\hline 1 & APO05 Manage portfolio & - & \multicolumn{1}{|c|}{ pahamnya dalam } \\
\hline 2 & APO07 Manage human resources & Ya & $\begin{array}{l}\text { Kurang } \\
\text { penggunaan layanan TI }\end{array}$ \\
\hline 3 & APO09 Manage service agreements & Ya & $\begin{array}{l}\text { Menurunnya tingkat ketersediaan } \\
\text { layanan }\end{array}$ \\
\hline 4 & APO10 Manage suppliers & - & \\
\hline 5 & APO12 Manage risk & - & \\
\hline 6 & APO13 Manage security & - & \\
\hline 7 & $\begin{array}{l}\text { BAI01 Manage programmes and } \\
\text { projects }\end{array}$ & - & $\begin{array}{l}\text { Ya } \\
\text { BAI02 Manage requirements } \\
\text { definition }\end{array}$ \\
\hline
\end{tabular}




\begin{tabular}{|c|c|c|c|}
\hline 9 & $\begin{array}{l}\text { BAI04 Manage availability and } \\
\text { capacity }\end{array}$ & $\mathrm{Ya}$ & $\begin{array}{l}\text { Menurunnya tingkat ketersediaan } \\
\text { layanan dan Lambannya dalam } \\
\text { mengatasi permasalahan yang ada }\end{array}$ \\
\hline 10 & BAI06 Manage changes & - & \\
\hline 11 & $\begin{array}{l}\text { BAI07 Manage change acceptance and } \\
\text { transitioning }\end{array}$ & - & \\
\hline 12 & BAI08 Manage knowledge & $\mathrm{Ya}$ & $\begin{array}{l}\text { Lambannya dalam mengatasi } \\
\text { permasalahan yang ada }\end{array}$ \\
\hline 13 & BAI09 Manage assets & - & \\
\hline 14 & BAI10 Manage configuration & - & \\
\hline 15 & DSS01 Manage operations & Ya & $\begin{array}{l}\text { Lambannya dalam mengatasi } \\
\text { permasalahan yang ada }\end{array}$ \\
\hline 16 & $\begin{array}{l}\text { DSSO2 Manage service requests and } \\
\text { incidents }\end{array}$ & Ya & $\begin{array}{l}\text { Lambannya dalam mengatasi } \\
\text { permasalahan yang ada }\end{array}$ \\
\hline 17 & DSS03 Manage problems & $\mathrm{Ya}$ & $\begin{array}{l}\text { Lambannya dalam mengatasi } \\
\text { permasalahan yang ada }\end{array}$ \\
\hline 18 & DSS04 Manage continuity & $\mathrm{Ya}$ & $\begin{array}{l}\text { Lambannya dalam mengatasi } \\
\text { permasalahan yang ada }\end{array}$ \\
\hline 19 & DSS05 Manage security services & - & \\
\hline 20 & $\begin{array}{l}\text { DSS06 Manage business process } \\
\text { controls }\end{array}$ & - & \\
\hline
\end{tabular}

Dari tabel 4.2 diatas dapat dilihat terdapat sembilan (9) proses-proses baru yang relevan dengan permasalahan yang dihadapi oleh Sekolah Tinggi Teknologi Indonesia Tanjungpinang. Dari proses-proses baru tersebut akan dilakukan pengukuran Tingkat Evaluasi Framework Tata Kelola Teknologi Informasi pada Sekolah Tinggi Teknologi Indonesia Tanjungpinang

\subsection{Hasil}

Hasil Pengukuran Tingkat Evaluasi Framework Tata Kelola Teknologi Informasi dapat dilihat pada diagram radar berikut untuk mengetahui perhituangan gap terhadap masingmasing point pertanyaan sesuai dengan target organisasi. 


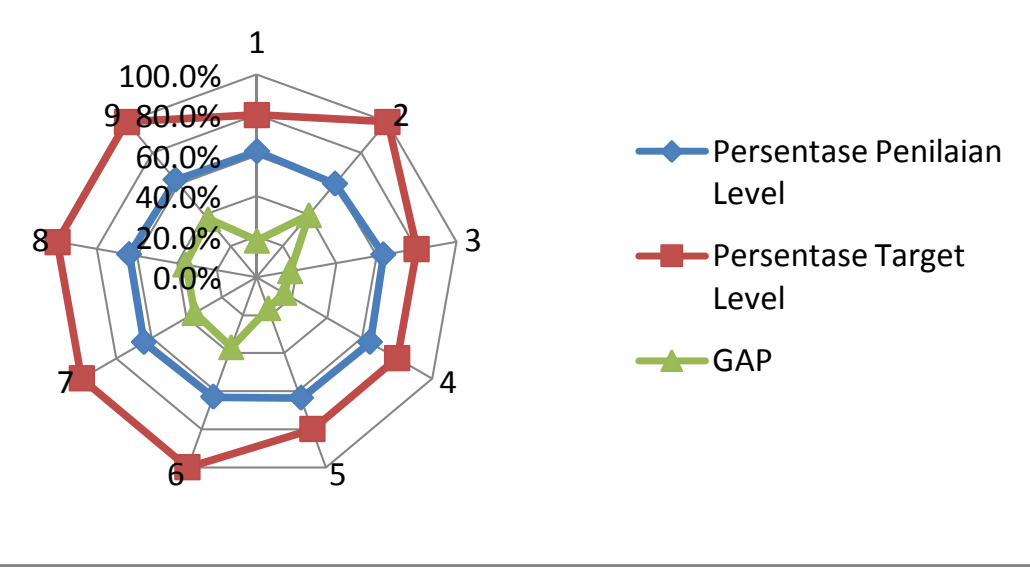

Gambar 4.1 Diagram Radar Hasil Pengukuran Tingkat Evaluasi Framework Tata Kelola Teknologi Informasi

Dari hasil yang telah diperoleh baik itu melalui tahapan penyebaran kuisioner dapat dilihat hasil kesenjangan dari kondisi saat ini dengan kondidi yang diharapkan institusi terlihat pada tabel dibawah ini:

Tabel 4.3 Tingkat Penilaian Level Domain APO, BAI, dan DSS

\begin{tabular}{|c|c|c|c|c|c|}
\hline Domain & $\begin{array}{l}\text { Proses } \\
\text { ID }\end{array}$ & Process & $\begin{array}{l}\text { Penilaian } \\
\text { saat ini }\end{array}$ & Target & GAP \\
\hline \multirow{2}{*}{$\begin{array}{l}\text { Align, Plan } \\
\text { and } \\
\text { Organise }\end{array}$} & APO07 & $\begin{array}{ll}\text { Manage } & \text { Human } \\
\text { Resources } & \end{array}$ & 3.10 & 4 & 0.90 \\
\hline & APO09 & $\begin{array}{ll}\text { Manage } & \text { Service } \\
\text { Agreements } & \end{array}$ & 3.00 & 5 & 2.00 \\
\hline \multirow{3}{*}{$\begin{array}{l}\text { Build, } \\
\text { Acquire and } \\
\text { Implement }\end{array}$} & BAI02 & $\begin{array}{l}\text { Manage } \\
\text { Requirements } \\
\text { Definition }\end{array}$ & 3.17 & 4 & 0.83 \\
\hline & BAI04 & $\begin{array}{l}\text { Manage Availability } \\
\text { and Capacity }\end{array}$ & 3.22 & 4 & 0.78 \\
\hline & BAI08 & Manage Knowledge & 3.18 & 4 & 0.82 \\
\hline \multirow{4}{*}{$\begin{array}{l}\text { Deliver, } \\
\text { Service and } \\
\text { Support }\end{array}$} & DSS01 & Manage Operations & 3.15 & 5 & 1.85 \\
\hline & DSS02 & $\begin{array}{lr}\text { Manage } & \text { Service } \\
\text { Requests } & \text { and } \\
\text { Incidents } & \\
\end{array}$ & 3.22 & 5 & 1.78 \\
\hline & DSS03 & Manage Problems & 3.21 & 5 & 1.79 \\
\hline & DSS04 & Manage Continuity & 3.13 & 5 & 1.87 \\
\hline \multicolumn{3}{|c|}{ Rata-rata tingkat penilaian level } & 3.15 & 4.56 & 1.40 \\
\hline
\end{tabular}

Rata-rata hasil penilaian kesenjangan kondisi saat ini dengan yang yang diharapkan yaitu sekitar 1,40, dimana berarti masih terdapat beberapa kelemahan yang terkait tata kelola teknologi informasi. Dari rekap hasil analisis pada setiap domain APO, BAI, dan DSS dapat 
dilihat pencapaian tingkat level proses pencapaian tata kelola teknologi informasi, dimana dari setiap domain yang masih menghasilkan nilai yang rendah akan dilakukan perbaikan. Domain yang masih berada pada level terendah yaitu domain APO09, APO07, DSS04, DSS01 yang dapat dilihat dari diagram batang berikut:

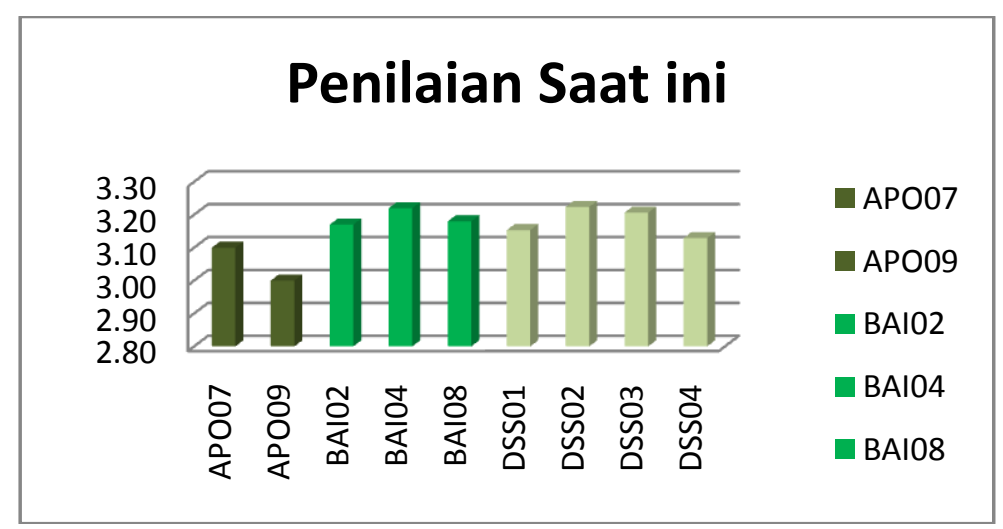

Gambar 4.2 Diagram Batang Level Domain APO, BAI, dan DSS

\subsection{Rekomendasi Perbaikan Layanan TI}

Pembuatan rekomendasi dilakukan untuk menjamin bahwa tujuan dan target yang diinginkan dapat tercapai. Rekomendasi diberikan pada setiap domain yang nilai levelnya masih rendah dari target yang diharapkan.

Tabel 4.4 Rekomendasi Perbaikan Layanan TI

\begin{tabular}{|c|c|c|}
\hline Domain & $\begin{array}{l}\text { Proses } \\
\text { ID }\end{array}$ & Strategi Perbaikan \\
\hline \multirow{4}{*}{$\begin{array}{l}\text { Align, } \\
\text { Plan and } \\
\text { Organise }\end{array}$} & \multirow[t]{2}{*}{ APO07 } & $\begin{array}{l}\text { Mengevaluasi kebutuhan kepegawaian secara teratur atau berdasarkan } \\
\text { perubahan besar untuk memastikan bahwa: } \\
\text { Memiliki sumber daya IT yang cukup untuk memadai dan tepat } \\
\text { mendukung perusahaan dan tujuan }\end{array}$ \\
\hline & & $\begin{array}{l}\text { Mempertahankan bisnis dan rekuitmen pegawai IT dan proses } \\
\text { penyimpanan sesuai dengan prosedur dan kebijakan personil perusahaan } \\
\text { secara keseluruhan. }\end{array}$ \\
\hline & \multirow[b]{2}{*}{ APO09 } & Mengembangkan layanan berbasis IT Katalog \\
\hline & & $\begin{array}{l}\text { Terus-menerus memastikan bahwa komponen layanan dalam portofolio } \\
\text { dan layanan terkait Katalog lengkap dan up to date. }\end{array}$ \\
\hline \multirow{2}{*}{$\begin{array}{l}\text { Build, } \\
\text { Acquire } \\
\text { and } \\
\text { Implement }\end{array}$} & \multirow{2}{*}{ BAI02 } & $\begin{array}{l}\text { Menetapkan dan melaksanakan pendefinisian prosedur dan pemeliharaan } \\
\text { prosedur dan prosedur repositori yang sesuai dengan ukuran, } \\
\text { kompleksitas, tujuan dan risiko bahwa perusahaan sedang melakukan } \\
\text { inisiatif pertimbangan }\end{array}$ \\
\hline & & $\begin{array}{l}\text { Melibatkan para pemangku kepentingan untuk membuat daftar kualitas } \\
\text { potensi, fungsional, dan persyaratan teknis dan risiko yang berkaitan } \\
\text { dengan pengolahan informasi }\end{array}$ \\
\hline
\end{tabular}




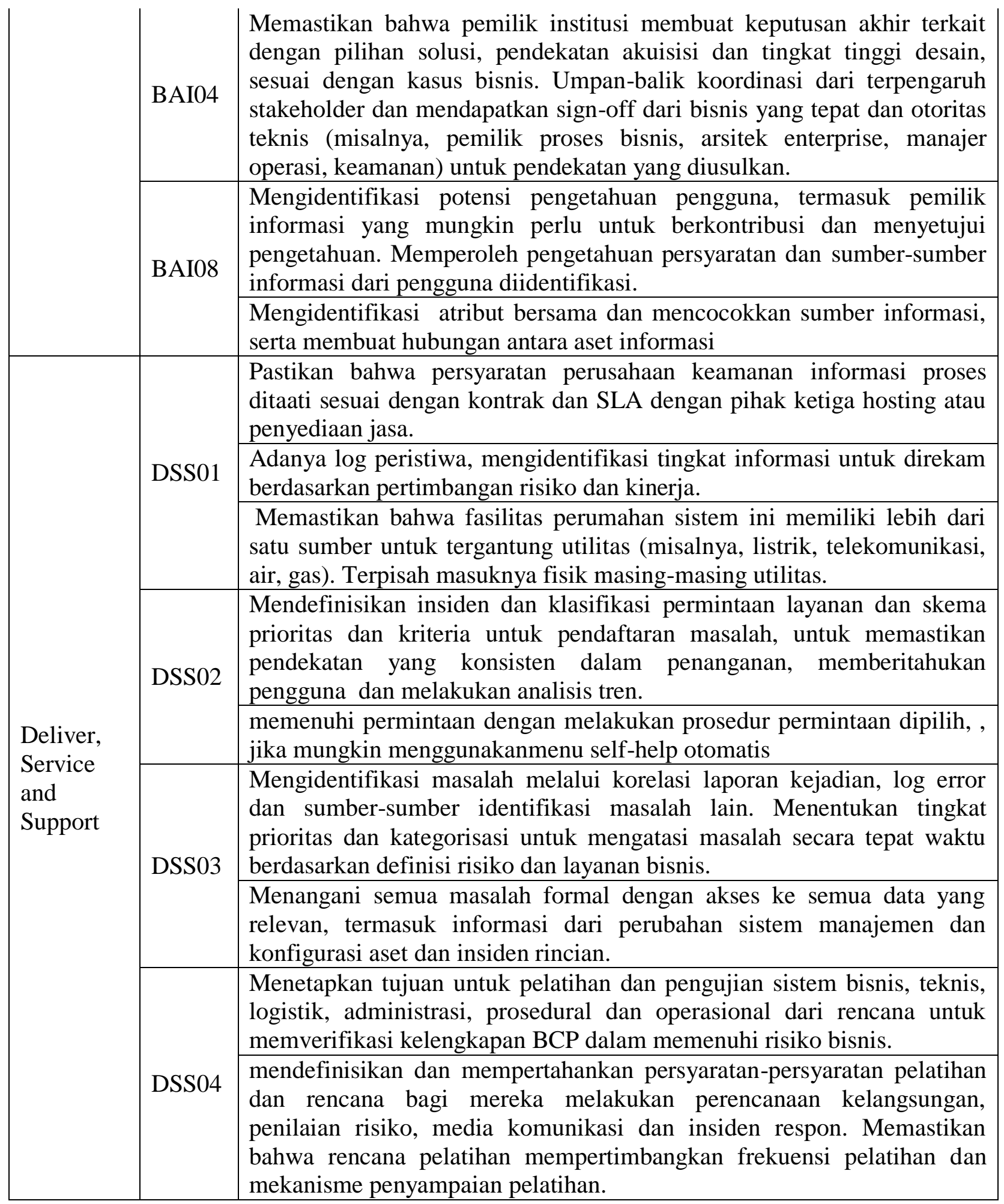




\section{KESIMPULAN}

1. Kerangka kerja tata kelola untuk layanan TI yang dibangun dengan pendekatan COBIT 5 dan ITIL V.3 menghasilkan proses-proses COBIT 5 baru yang digunakan untuk pengukuran tingkat evaluasi framework tata kelola teknologi informasi pada Sekolah Tinggi Teknologi Indonesia Tanjungpinang

2. $\quad$ Strategi perbaikan layanan TI yang perlu dilakukan oleh STTI Tanjungpinang mengacu pada rekomendasi perbaikan layanan TI yang akan diberikan kepada pemilik institusi untuk membuat keputusan akhir terkait tata kelola teknologi informasi yang berhubungan dengan sumber daya IT, layanan IT, prosedur dan pemeliharaan IT, serta rencana dalam menangani jika terjadi insiden pada IT.

\section{DAFTAR PUSTAKA}

[1] Almeida, R, Pinto, Pedro \& da Silva, Miquel Mira, 2016, Using ArchiMate to Assess COBIT 5 and ITIL Implementations, International Conference on Information Systems Development (ISD)

[2] ISACA, 2013, COBIT 5 Enabling Information, USA

[3] ISACA, 2012, COBIT 5 a Business Framework for the Governance and Management of Enterprise IT Personal, USA

[4] Martono, Nanang, 2014, Dunia Lebih Indah Tanpa Sekolah, Mitra Wacana media, Bogor

[5] Nuryanto, Hery, 2012, Sejarah Perkembangan Teknologi Informasi dan Komunikasi, Edisi Pertama, PT. Balai Pustaka (Persero), Jakarta Timur

[6] Samiotakis, Michalis, 2013, Integrating ITIL and COBIT 5 to Optimize IT Process and Service Delivery, ISACA Athens Chapter, South East Europe Conference

[7] Tarigan, Josua, Purbo, Onno dan Ridwan Sanjaya, 2010, Bussines-Driven Information System, PT Elex Media Komputindo, Jakarta

[8] The Art of Service, 2009, Managing Across the Lifecycle Best Pratices, Office Of Government Commerce, London

[9] Zeinolabedin, Narges, Soroush Afiati Mehrvarz, and Neda Rahbar, 2014, How COBIT Can Complement ITIL to Achieve Bit, Electrical \& Computer Engineering: An International Journal (ECIJ) Volume 3, Number 2, June 2014 